\title{
A Message from the President
}

By Robert W. Nero, Regina

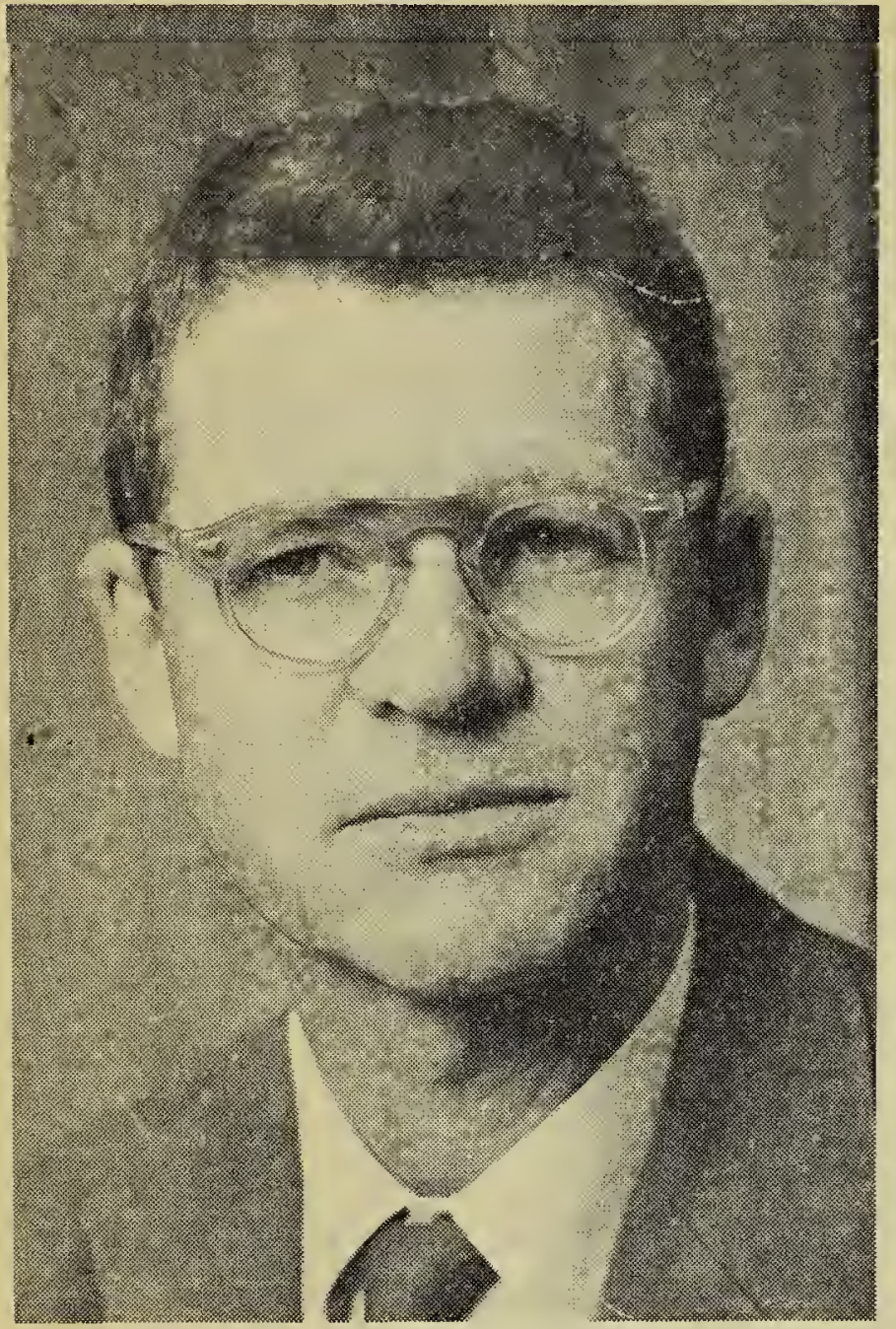

Sask. Photo Services.

ROBERT W. NERO

Judging from the comments made by people at the A.O.U. meeting, the Blue Jay is one of the most respected natural ristory journals on the continent. Mrs. Priestly would undoubtedly be proud of us. In going back over Mrs. Priestly's Blue Jays I am reminded to what extent she was interested in recording accurate original observations. I think that the present Blue Jay conforms nicely to her policies. I think that we are also in complete agreement with her in believing that conservation includes the study and understanding, as well as the appreciation, of our natural environment. Research-and by this I include all factual recording, all original studies-provides the basis for a better understanding of the environment; furthermore, it also provides a sound basis for management, particularly from our point of view which attempts to ensure some preservation of the natural aspect.

I think the Society should encour- age research in natural history by all possible bodies, by the governments, the universities, museums and other agencies. I also hope that the next year will see an increased amount of study by members themselves. Even the simplest study is in the nature of an exploration and can bring personal satisfaction because of this.

Our local societies can do much to promote studies by members. The Prince Albert society has organized a group research project to attempt a complete biological inventory of a mixed wood forest area north of Christopher Lake. It is unlikely that this has ever been done in Saskatchewan and we wish these ambitious members the best of luck in their undertaking. Tr.is kind of inventory is needed for every different habitat in the province.

Aldo Leopold in his Sand County Almanac (this is one book every member should read) has seen the possibilities of such amateur research. "The more difficult and laborious research problems must doubtless remain in professional hands," he says, "but there are plenty of problems suitable for all grades of amateurs." He cites the classic examples of 'Margaret Nice, who studied song sparrows in rer back yard and became a world authority on bird behaviour; of Charles L. Broley, a banker who banded eagles for fun and discovered a hitherto unknown fact: that some eagles nest in the south in winter and then go vacationing to the north woods; of Norman and Stuart Criddle, wheat ranchers on the Manitoba prairies, who studied the fauna and flora of their farm, and became recognized authorities on everything from local botany to wildlife cycles; of Elliott S. Barker, a cowman in the New Mexico mountains, who wrote one of the two best books on that elusive cat: the mountain lion. Then he adds, and I should like to leave these words of Leopold with every member of our society: "Do not let anyone tell you that these people made work out of play. They simply realized that the most fun lies in seeing and studying the unknown." 